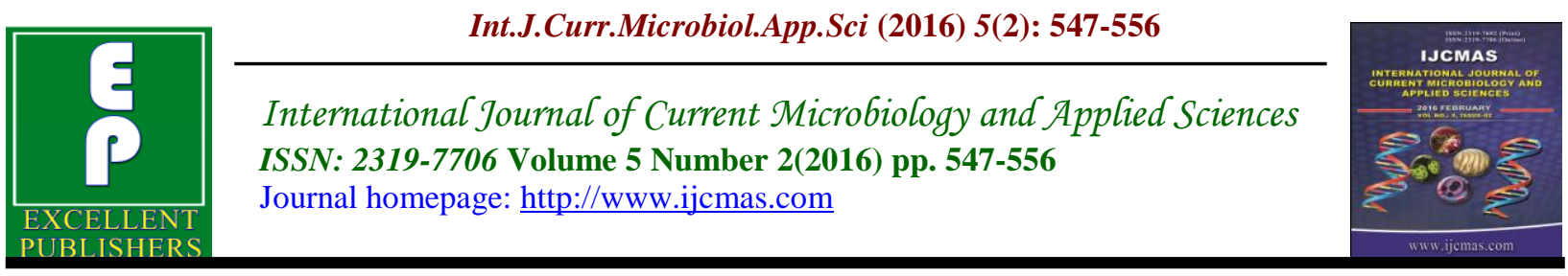

Original Research Article

doi: http://dx.doi.org/10.20546/ijcmas.2016.502.062

\title{
Isolation and Screening of Fungi for the Production of Xylanase Using Solid- State Fermentation from Sirsi Region of Western Ghats of Karnataka, India
}

\author{
Anilkumar Hegde ${ }^{1 *}$ and Ch. Ramesh ${ }^{2}$ \\ ${ }^{1}$ Dept of Biotechnology, M.E.S M.M.Arts \& Science College, Sirsi, Karnataka, India \\ ${ }^{2}$ Dept of Botany, Karnatak University, Dharwad, Karnataka, India \\ *Corresponding author
}

\begin{tabular}{ll}
\hline A B S T R A C T \\
\cline { 2 - 3 } $\begin{array}{l}\text { Keywords } \\
\text { Fungi, }\end{array}$ Xylanases, \\
$\begin{array}{l}\text { Solid-state } \\
\text { fermentation, } \\
\text { Paddy straws. }\end{array}$ & $\begin{array}{l}\text { Xylanases show great potential for industrial applications. The extracellular } \\
\text { xylanases are considered important from the industrial viewpoint as they ease the } \\
\text { extraction procedure. Although a number of xylanase productions were performed } \\
\text { using submerged systems, solid state fermentation was found to be more } \\
\text { economical mainly due to the cheap and abundant availability of agricultural } \\
\text { wastes which can be used as substrates. The present study is an attempt to isolate } \\
\text { and identify the fungi and to screen them for the production of Xylanase using } \\
\text { solid-state fermentation from Sirsi region of Western ghats of Karnataka. In the } \\
\text { present study paddy straw substrate was used for xylanase production by Humicola }\end{array}$ \\
$\begin{array}{ll}\text { Accepted: } \\
\text { 26 January 2016 } \\
\text { Available Online: } \\
\text { 10, February 2016 }\end{array}$ & $\begin{array}{l}\text { lanuginosus, in SSF with the growth of 0.9 mg glucosamine/g substrate and } \\
\text { xylanase production of 9.5 U/g substrate. Aspergillus fumigatus produced 0.75 mg } \\
\text { glucosamine/g substrate and xylanase production of } 7.5 \text { U/g substrate. }\end{array}$
\end{tabular}

\section{Introduction}

Xylanases show great potential for industrial applications mainly for the bioconversion of lignocelluloses to sugar, ethanol, and other useful substances, clarification of juices and wines, improving the nutritional quality of silage and green feed and the de-inking processes of waste papers (Viikari et al., 2001). Haltrich et al., (1996) gave an overview of fungal xylanases and showed that the enzyme can be produced by a number of microorganisms including bacteria, yeasts and filamentous fungi such as Trichoderma, Bacillus, Cryptococcus, Aspergillus, Penicillium, Aureobasidium, Fusarium, Chaetomium, Phanerochaete,
Rhizomucor, Humicola, Talaromyces and many more. These fungi produced xylanase enzymes extra cellularly with a wide range of activities from 4-400 IU/ml using various substrates both in submerged and solid state fermentation (SSF) processes. Solid state fermentation method offers distinct advantages over submerged fermentation including economy of space needed for fermentation; simplicity of the fermentation media; no requirement for complex machinery, equipment and control systems; greater compactness of the fermentation vessel owing to a lower water volume; greater product yield; reduced energy 
demand; lower capital and low recurring expenditures in industrial operation; easier scale up processes; lesser volume of solvent needed for product recovery; superior yields; absence of foam build up; and easier control of contaminants due to the low moisture level in the system (Pandey,1992).

Agricultural wastes such as sugar cane bagasse, paddy straw, and rice husks wastes contribute to more than 5 million tones of wastes per year. Based on the enormous amount of wastes, there is an urgent need to manage the bulk wastes effectively and economically. At the same time, it is also necessary to generate value added products from these wastes. SSF has been used for the production of fine chemicals of commercial value from microbial sources such as enzymes, antibiotics, flavouring compounds and also microbial biomass which was used as animal feeds.

\section{Materials and Methods}

\section{Microorganisms used and Screening of the Xylanolytic Activities}

The fungal isolates formed were sub cultured to purity and examined for xylanolytic activities. Screening for xylanolytic activities was performed on malt extract agar (MEA) containing $0.1 \%(\mathrm{w} / \mathrm{v})$ of xylan from oat spelt. Positive xylanolytic isolates were detected based on the clear zones of hydrolysis on the xylan. The potential isolates were sub cultured and maintained on MEA slants. The slants were stored at $4^{\circ} \mathrm{C}$ prior to use.

\section{Solid-state Fermentation Cultivation Systems}

(SSF)

Cultivation of fungus was performed in 250 $\mathrm{ml}$ Erlenmeyer flask containing $10 \mathrm{~g}$ of solid substrate with the addition of $15 \mathrm{ml}$ of
Mandel's medium. The Mandel's medium was prepared with the following composition (g/l) 10.0g; urea, 0.3; peptone, 0.75 ; yeast extract, $0.25 ;\left(\mathrm{NH}_{4}\right)_{2} \mathrm{SO}_{4}, 1.4$; $\mathrm{KH}_{2} \mathrm{PO}_{4}, 2.0 ; \mathrm{CaCl}_{2}, 0.3 ; \mathrm{MgSO}_{4} .7 \mathrm{H} 2 \mathrm{O}, 0.3$ and trace elements $(\mathrm{mg} / \mathrm{l}): \mathrm{FeSO}_{4} \cdot 7 \mathrm{H}_{2} \mathrm{O}, 5$; MnSO4. $4 \mathrm{H}_{2} \mathrm{O}, 1.6 ; \mathrm{ZnSO}_{4} .7 \mathrm{H}_{2} \mathrm{O}, 1.4$ and $\mathrm{CoCl}_{2} \cdot 6 \mathrm{H}_{2} \mathrm{O}, 20.0$ (Mandels et al., 1976). The medium and the trace elements were autoclaved separately. The flask was cooled down at room temperature and a known amount of sterilized trace elements was added. The flasks were then inoculated with $1 \times 10^{-6}$ spores/ $\mathrm{ml}$ of the moistening agent and incubated for 7 days at the temperature $\left(25 \pm 1^{\circ} \mathrm{C}\right)$. The inoculum was prepared by growing the isolate on malt extract agar at $37^{\circ} \mathrm{C}$ until sporulation. The spores were harvested using $0.1 \%$ Tween 80 (Smith et al., 1996).

\section{Enzyme Extraction}

$70 \mathrm{ml}$ of cold distilled water $\left(4^{\circ} \mathrm{C}\right)$ was added to the SSF medium (10 g substrate) after cultivation. The mixture was vigorously homogenized for 30 minutes at $200 \mathrm{rpm}$. The solid biomass residues were separated from the suspension by filtration through Whatmann filter paper No.1. The cell free supernatant was used as the source of crude enzyme preparation.

\section{Optimization of Medium Composition and Cultural Conditions}

The optimization of medium composition and cultural conditions were carried out based on the step wise modifications of the governing parameters for xylanase production. The effect of various substrates for SSF, consisting of, sugar cane bagasse, corn cobs, paddy straw and wheat bran, was examined by adding $10 \mathrm{~g}$ of each substrate in a 250-ml Erlenmeyer flask with $10 \mathrm{ml}$ of distilled water which was added to moisture 
the substrates. Cultivations were carried out at temperature $\left(25 \pm 1^{\circ} \mathrm{C}\right)$ for 7 days. The effect of moisture level on the enzyme production was determined by varying the ratio $(\mathrm{w} / \mathrm{v})$ of substrate to moistening agent at the ratio of 1:0.5, 1:0.75, 1:1.0 and 1:1.25. The moistening agent used was sterile distilled water. The effect of mineral salts solution and tap water as moistening agents on xylanase production was also determined as comparison to that of distilled water. The mineral salts solution used consist of $(\mathrm{g} / \mathrm{l})$ : $\mathrm{FeSO}_{4}$. $\quad 7 \mathrm{H}_{2} \mathrm{O}, \quad 5 ; \quad \mathrm{MnSO}_{4} .4 \mathrm{H}_{2} \mathrm{O}, \quad$ 1.6; $\mathrm{ZnSO}_{4} .7 \mathrm{H}_{2} \mathrm{O}, 1.4$ and $\mathrm{CoCl}_{2} \cdot 6 \mathrm{H}_{2} \mathrm{O}, 20.0$

The effect of cultivation temperatures on the enzyme production was examined at temperature $\left(25 \pm 1^{\circ} \mathrm{C}\right), 30,35$ and $40^{\circ} \mathrm{C}$. Cultivations were carried out for 7 days.

The effect of inoculum size was determined by adding the spore suspension of concentration of $1 \times 10^{3}, 1 \times 10^{4}$ and $1 \times 10^{5}$ spores/ml prepared using the moistening agent for moisture control in the SSF system. Cultivations were carried out at temperature $\left(25 \pm 1^{\circ} \mathrm{C}\right)$ for 7 days.

The effect of supplementation of additional carbon and nitrogen sources to substrates was examined using carbon sources consisting of glucose, xylose, malt extract, lactose, maltose or xylan at $5 \%(\mathrm{w} / \mathrm{w})$. Similarly, the nitrogen sources examined were peptone, urea, $\mathrm{NaNO}_{3}$, yeast extract, $\left(\mathrm{NH}_{4}\right)_{2} \mathrm{SO}_{4}$ and $\mathrm{NH}_{4} \mathrm{NO}_{3}$ at $0.075 \%(\mathrm{w} / \mathrm{w})$. The optimum concentrations of the carbon and nitrogen sources were also determined. Cultivations were carried out at temperature $\left(25 \pm 1^{\circ} \mathrm{C}\right)$ for 7 days.

\section{Analyses}

Xylanase activity was assayed using the method of Gessesse and Gashe, (1997) at $25 \pm 1^{\circ} \mathrm{C}$ using $1 \%(\mathrm{w} / \mathrm{v})$ oat spelt xylan as the substrate, which was dissolved in $50 \mathrm{mM}$ citrate buffer, $\mathrm{pH}$ 4.5. One unit of xylanase activity is defined as the amount of enzyme that releases $1 \mu \mathrm{mol}$ of reducing sugar equivalent to xylose per minute. Xylanase production was expressed as units (U) per gram of dry weight of substrate. Growth of the fungus was determined by the method of glucosamine as described by Swift (1972). Growth of the fungus was expressed as mg glucosamine per $\mathrm{g}$ of substrate.

\section{Results and Discussion}

\section{Selection of Fungi}

Based on the screening tests, a total of 5 isolates were capable of exhibiting xylanolytic activities on MEA-xylan agar with the diameter of the clear zones ranging from 3.5-4.5 cm. they are Humicola lanuginosus, Talaromyces duponti, Chaetomium globosum, Malbranchea surfia, Aspergillus fumigatus. Further, Humicola lanuginosus, and Aspergillus fumigatus were used for the solid state fermentation as they show highest clearance zone as $4.5 \mathrm{~cm}$ and $4.2 \mathrm{~cm}$ respectively.

Optimization of cultural conditions and medium composition for the production of xylanase

\section{Effect of Substrate Types}

Agricultural wastes such as sugar cane baggase, paddy straws, corn cobs and wheat bran were examined as substrates. It revealed that paddy straw substrate for xylanase production by Humicola lanuginosus, in SSF with the growth of 0.9 mg glucosamine/g substrate and xylanase production of $9.5 \mathrm{U} / \mathrm{g}$ substrate whereas Aspergillus fumigatus $0.75 \quad \mathrm{mg}$ glucosamine/g substrate and xylanase production of $7.5 \mathrm{U} / \mathrm{g}$ substrate. (Table 1 Fig 1) 


\section{Effect of Cultivation Temperature}

Temperature is one of the important parameters that determine the success of SSF system. Therefore, the effect of temperature on xylanase production by Humicola lanuginosus, and Aspergillus fumigatus, was examined. Humicola lanuginosus, showed the maximum production of xylanase activity at $50^{\circ} \mathrm{C}$ with an activity of $14.4 \mathrm{U} / \mathrm{g}$ and the growth about $1.8 \mathrm{mg}$ glucosamine/ g substrate. A lower activity in the range of $2-10 \mathrm{U} / \mathrm{g}$ and growth of about $1.2 \mathrm{mg}$ glucosamine/ $\mathrm{g}$ substrate were obtained. Aspergillus fumigatus showed the maximum production of xylanase activity at $45^{\circ} \mathrm{C}$ with an activity of $11.50 \mathrm{U} / \mathrm{g}$ and the growth about $1.75 \mathrm{mg}$ glucosamine/ $g$ substrate. A lower activity in the range of $2.34 \mathrm{U} / \mathrm{g}$ and growth of about $1.12 \mathrm{mg}$ glucosamine/ $\mathrm{g}$ substrate were obtained (Table 2).

\section{Effect of Moisture Content}

Humicola lanuginosus, the xylanase production was optimum using the paddy straw which was moistened with moistening agent in the ratio of 1:0.75 with the production of $19.5 \mathrm{U} / \mathrm{g}$ substrate and growth of $1.6 \mathrm{mg}$ glucosamine/g substrate. Minimum production of xylanase $8.50 \mathrm{U} / \mathrm{g}$ substrate and growth of $0.9 \mathrm{mg}$ glucosamine/g substrate. Aspergillus fumigatus the xylanase production was optimum with moistening agent in the ratio of 1:0.75 with the production of $15.50 \mathrm{U} / \mathrm{g}$ substrates and growth of $1.25 \mathrm{mg}$ glucosamine/g substrate. Minimum production of xylanase $7.64 \mathrm{U} / \mathrm{g}$ substrate and growth of $0.84 \mathrm{mg}$ glucosamine/g substrate. Besides distilled water, other moistening agents consisting of mineral salt solution and tap water were also examined. Humicola lanuginosus, and Aspergillus fumigatus mineral salts solution and tap water resulted higher xylanase production compared to distilled water. However, the enzyme production using tap water of 24.23 $\mathrm{U} / \mathrm{g}$ showed no significant difference from that of using the mineral salts solution of $25.12 \mathrm{U} / \mathrm{g}$. and $20.15 \mathrm{U} / \mathrm{g}$ and 18.35 respectively Thus, tap water was chosen as the moistening agent for economical reasons (Table 4).

\section{Effect of Supplementation of Additional Carbon and Nitrogen Sources}

In case of xylose Humicola lanuginosus, showed the maximum production of xylanase activity of $28.50 \mathrm{U} / \mathrm{g}$ and the growth about $2.20 \mathrm{mg}$ glucosamine/ $\mathrm{g}$ substrate. A lower xylanase activity of 15.34 $\mathrm{U} / \mathrm{g}$ and growth of about $1.05 \mathrm{mg}$ glucosamine/ $g$ substrate were obtained in case of control where there is no addition of any of the sugar. Aspergillus fumigatus showed the maximum production of xylanase activity of $22.50 \mathrm{U} / \mathrm{g}$ and the growth about $2.12 \mathrm{mg}$ glucosamine/ $\mathrm{g}$ substrate. Here also xylose showed maximum activity. A lower xylanase activity of $10.45 \mathrm{U} / \mathrm{g}$ and growth of about $0.85 \mathrm{mg}$ glucosamine/ $\mathrm{g}$ substrate were obtained in case of control where there is no addition of any of the sugar. Next to xylose, maltose, lactose also showed good activity. In case of cellulose the xylanase activity is less when compare to Xylose (Table 5).

Among different nitrogen sources used sodium nitrate showed maximum activity, Humicola lanuginosus, showed the maximum production of xylanase activity of $32.10 \mathrm{U} / \mathrm{g}$ and the growth about $2.45 \mathrm{mg}$ glucosamine/ $g$ substrate. A lower xylanase activity of $20.65 \mathrm{U} / \mathrm{g}$ and growth of about $1.65 \mathrm{mg}$ glucosamine/ $\mathrm{g}$ substrate were obtained in case of control where there is no addition of any of the nitrogen source was added. Aspergillus fumigatus showed the maximum production of xylanase activity of $26.65 \mathrm{U} / \mathrm{g}$ and the growth about $1.65 \mathrm{mg}$ 
glucosamine/g substrate. A lower xylanase activity of $14.50 \mathrm{U} / \mathrm{g}$ and growth of about $0.85 \mathrm{mg}$ glucosamine/ $\mathrm{g}$ substrate were obtained in case of control where there is no addition of any of the nitrogen source. Next to sodium nitrate, yeast extract and ammonium nitrate also showed good activity. In case of urea the xylanase activity is less when compare to sodium nitrate (Table 6 ).

Optimization of cultural conditions and medium composition for the production of xylanase

\section{Effect of Substrate Types}

In the present study paddy straw substrate was used for xylanase production by Humicola lanuginosus, in SSF with the growth of $0.9 \mathrm{mg}$ glucosamine/g substrate and xylanase production of $9.5 \mathrm{U} / \mathrm{g}$ substrate. Aspergillus fumigatus produced $0.75 \mathrm{mg}$ glucosamine/g substrate and xylanase production of $7.5 \mathrm{U} / \mathrm{g}$ substrate. Other substrates like cane bagasse, and maize straw, and corn cobs although supporting the growth were in the range of less than $0.5 \mathrm{mg}$ glucosamine/g substrate, but did not allow any synthesis of xylanase by the fungus. The xylanase activity observed was only in the range of less than $0.2 \mathrm{U} / \mathrm{g}$ substrate.

The high growth of the fungus on paddy straw corresponded closely to the production of xylanase. The suitability of paddy straw as substrate is related to the nutritional content of the substrate. Paddy straw has higher protein content of $16 \%$ compared to other substrates which are in the range of 13\% (Pandey, 1992). At the same time, the particle size of paddy straw was relatively smaller than other substrates giving a higher surface area which would ease oxygen diffusion and nutrient absorption and assimilation by the mycelia.

Table.1 SSF Cultivation Systems by Humicola Lanuginosus, and Aspergillus Fumigatus on Four Substrates Grown at Temperature $\left(25 \pm 1^{\circ} \mathrm{C}\right)$ for 7 Days

\begin{tabular}{|l|l|l|l|l|l|}
\hline \multicolumn{2}{|l|}{ S.No } & Substrate used & \multicolumn{2}{|l|}{ Humicola lanuginosus } & Aspergillus fumigatus \\
\hline \multicolumn{2}{|l|}{} & $\begin{array}{l}\text { Xylanase } \\
(\mathrm{U} / \mathrm{g})\end{array}$ & $\begin{array}{l}\text { Glucosamine } \\
(\mathrm{Mg} / \mathrm{g})\end{array}$ & $\begin{array}{l}\text { Xylanase } \\
(\mathrm{U} / \mathrm{g})\end{array}$ & $\begin{array}{l}\text { Glucosamine } \\
(\mathrm{Mg} / \mathrm{g})\end{array}$ \\
\hline 1 & Cane bagasse & 8.75 & 0.80 & 6.75 & 0.55 \\
\hline 2 & Paddy straw & 9.50 & 0.90 & 7.50 & 0.75 \\
\hline 3 & Corn cobs & 0.20 & 0.45 & 1.25 & 0.32 \\
\hline 4 & Maize straw & 5.00 & 0.46 & 2.45 & 0.42 \\
\hline
\end{tabular}

Table.2 Effect of Cultivation Temperature on SSF Cultivation Systems by Humicola Lanuginosus, and Aspergillus Fumigatus on Paddy Straw Substrates

\begin{tabular}{|l|l|l|l|l|l|}
\hline S.No & Paddy straw & \multicolumn{2}{l|}{ Humicola lanuginosus } & \multicolumn{2}{l|}{ Aspergillus fumigatus } \\
\hline \multicolumn{2}{|l|}{} & Xylanase $(\mathrm{U} / \mathrm{g})$ & Glucosamine $(\mathrm{Mg} / \mathrm{g})$ & Xylanase $(\mathrm{U} / \mathrm{g})$ & Glucosamine $(\mathrm{Mg} / \mathrm{g})$ \\
\hline 1 & $40^{\circ} \mathrm{C}$ & 2.50 & 1.20 & 10.45 & 1.45 \\
\hline 2 & $45^{\circ} \mathrm{C}$ & 10.50 & 1.64 & 11.50 & 1.75 \\
\hline 3 & $50^{\circ} \mathrm{C}$ & 14.40 & 1.80 & 9.25 & 1.22 \\
\hline 4 & $55^{\circ} \mathrm{C}$ & 9.60 & 1.35 & 2.34 & 1.12 \\
\hline
\end{tabular}


Table.3 Effect of the Ratio between the Substrate Paddy Straw to Added Distilled Water as Moistening Agent

\begin{tabular}{|l|l|l|l|l|l|}
\hline S.No & Moisture ratio & \multicolumn{3}{|l|}{ Humicola lanuginosus } & Aspergillus fumigatus \\
\hline \multicolumn{2}{|l|}{} & $\begin{array}{l}\text { Xylanase } \\
(\mathrm{U} / \mathrm{g})\end{array}$ & $\begin{array}{l}\text { Glucosamine } \\
(\mathrm{Mg} / \mathrm{g})\end{array}$ & $\begin{array}{l}\text { Xylanase } \\
(\mathrm{U} / \mathrm{g})\end{array}$ & $\begin{array}{l}\text { Glucosamine } \\
(\mathrm{Mg} / \mathrm{g})\end{array}$ \\
\hline 1 & 0.50 & 12.25 & 1.00 & 9.15 & 1.20 \\
\hline 2 & 0.75 & 19.50 & 1.60 & 15.20 & 1.25 \\
\hline 3 & 1.00 & 13.10 & 1.25 & 8.35 & 0.95 \\
\hline 4 & 1.25 & 8.50 & 0.95 & 7.64 & 0.84 \\
\hline
\end{tabular}

Table.4 Effect of Different Moistening Agents used

\begin{tabular}{|l|l|l|l|l|l|}
\hline S.No & $\begin{array}{l}\text { Moistening } \\
\text { agents }\end{array}$ & \multicolumn{2}{l|}{ Humicola lanuginosus } & \multicolumn{2}{l|}{ Aspergillus fumigatus } \\
\hline \multicolumn{7}{|l|}{} & $\begin{array}{l}\text { Xylanase } \\
(\mathrm{U} / \mathrm{g})\end{array}$ & $\begin{array}{l}\text { Glucosamine } \\
(\mathrm{Mg} / \mathrm{g})\end{array}$ & $\begin{array}{l}\text { Xylanase } \\
(\mathrm{U} / \mathrm{g})\end{array}$ & $\begin{array}{l}\text { Glucosamine } \\
(\mathrm{Mg} / \mathrm{g})\end{array}$ \\
\hline 1 & Tap water & 24.34 & 2.20 & 20.15 & 2.10 \\
\hline 2 & $\begin{array}{l}\text { Distilled } \\
\text { water }\end{array}$ & 18.50 & 1.94 & 13.20 & 1.65 \\
\hline 3 & Mineral salts & 25.12 & 2.05 & 18.35 & 1.92 \\
\hline
\end{tabular}

Table.5 Effect of Different Carbon Sources used

\begin{tabular}{|l|l|l|l|l|l|}
\hline S.No & $\begin{array}{l}\text { Different } \\
\text { carbon } \\
\text { sources }\end{array}$ & \multicolumn{2}{|l|}{ Humicola lanuginosus } & \multicolumn{2}{l|}{ Aspergillus fumigatus } \\
\hline & & $\begin{array}{l}\text { Xylanase } \\
(\mathrm{U} / \mathrm{g})\end{array}$ & $\begin{array}{l}\text { Glucosamine } \\
(\mathrm{Mg} / \mathrm{g})\end{array}$ & $\begin{array}{l}\text { Xylanase } \\
(\mathrm{U} / \mathrm{g})\end{array}$ & $\begin{array}{l}\text { Glucosamine } \\
(\mathrm{Mg} / \mathrm{g})\end{array}$ \\
\hline 1 & Lactose & 23.50 & 1.90 & 15.15 & 1.30 \\
\hline 2 & Malt extract & 24.40 & 1.80 & 14.70 & 1.25 \\
\hline 3 & Maltose & 25.12 & 1.70 & 16.45 & 1.42 \\
\hline 4 & Xylan & 22.10 & 1.45 & 15.75 & 1.38 \\
\hline 5 & Xylose & 28.50 & 2.20 & 22.50 & 2.12 \\
\hline 6 & Cellulose & 16.85 & 1.20 & 11.58 & 0.98 \\
\hline 7 & No addition & 15.34 & 1.05 & 10.45 & 0.85 \\
\hline
\end{tabular}


Table.6 Effect of Different Nitrogen Sources used

\begin{tabular}{|l|l|l|l|l|l|}
\hline S.No & $\begin{array}{l}\text { Different nitrogen } \\
\text { sources }\end{array}$ & \multicolumn{2}{l|}{ Humicola lanuginosus } & \multicolumn{2}{l|}{ Aspergillus fumigatus } \\
\hline & & $\begin{array}{l}\text { Xylanase } \\
(\mathrm{U} / \mathrm{g})\end{array}$ & $\begin{array}{l}\text { Glucosamine } \\
(\mathrm{Mg} / \mathrm{g})\end{array}$ & $\begin{array}{l}\text { Xylanase } \\
(\mathrm{U} / \mathrm{g})\end{array}$ & $\begin{array}{l}\text { Glucosamine } \\
(\mathrm{Mg} / \mathrm{g})\end{array}$ \\
\hline 1 & Peptone & 29.50 & 2.15 & 23.15 & 1.80 \\
\hline 2 & Urea & 29.40 & 2.10 & 24.80 & 1.95 \\
\hline 3 & Sodium nitrate & 32.10 & 2.45 & 26.75 & 1.68 \\
\hline 4 & Yeast extract & 30.16 & 2.20 & 23.55 & 1.88 \\
\hline 5 & Ammonium sulphate & 29.90 & 2.20 & 24.70 & 1.86 \\
\hline 6 & Ammonium nitrate & 30.15 & 2.12 & 20.42 & 1.04 \\
\hline 7 & No addition & 20.65 & 1.65 & 14.50 & 0.85 \\
\hline
\end{tabular}

Fig.1 SSF Cultivation Systems by Humicola Lanuginosus, and Aspergillus Fumigatus on Four Substrates Grown at Temperature $\left(25 \pm 1^{\circ} \mathrm{C}\right)$ for 7 Days

\section{A.Humicola Lanuginosus}
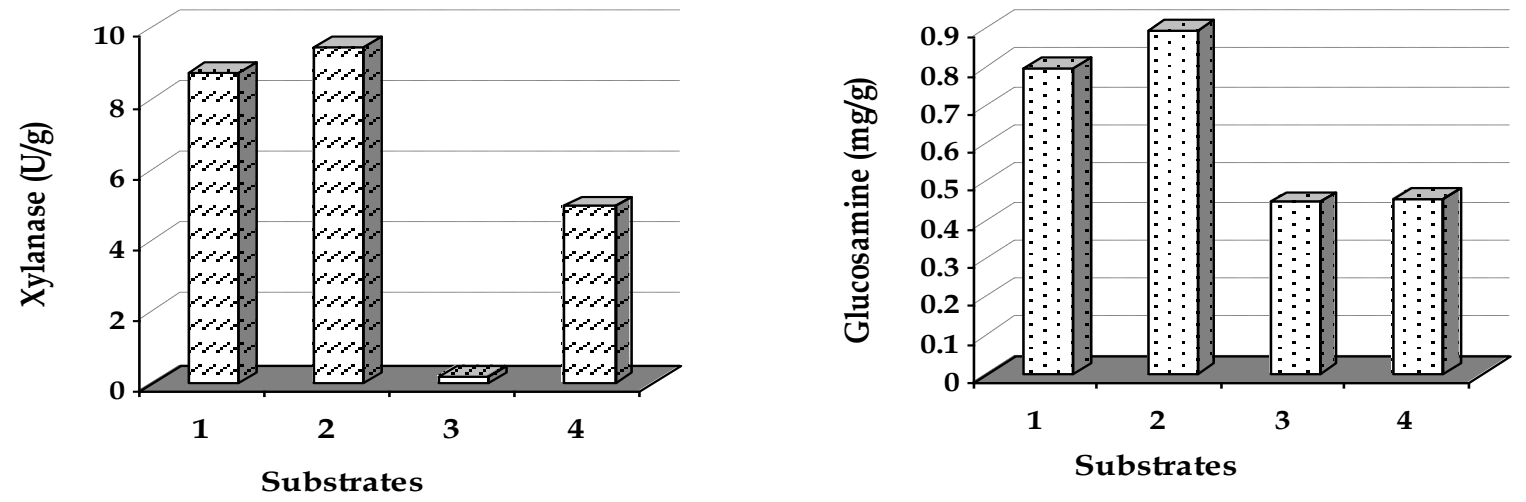

\section{B.Aspergillus Fumigatus}

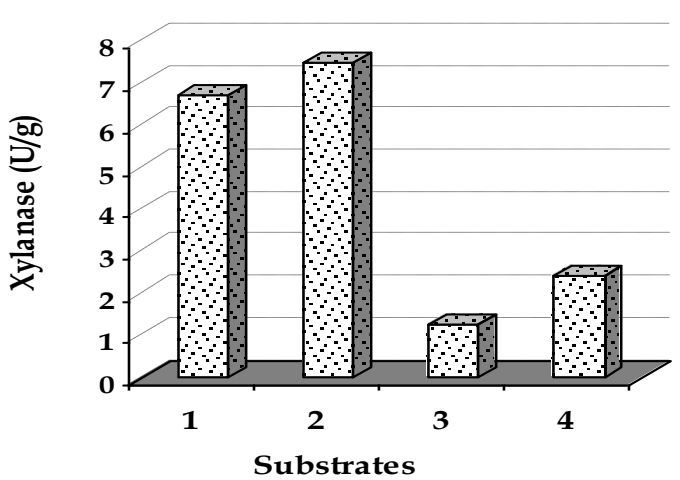

1. Cane bagasse
2. Paddy straw

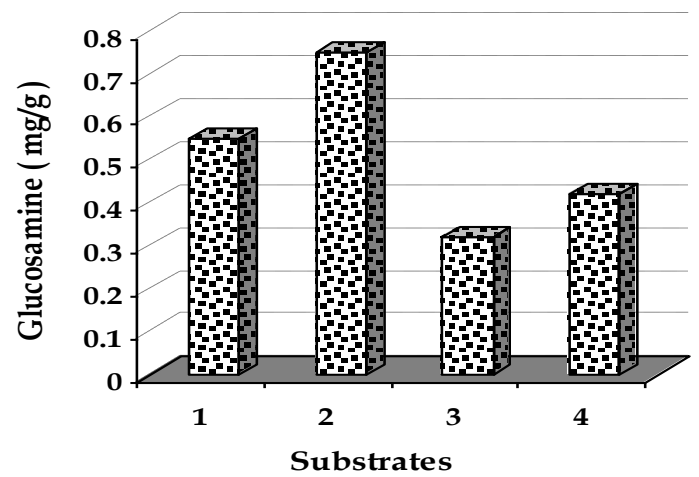

3. Corn cobs

4. Maize straw 


\section{Effect of Cultivation Temperature}

Humicola lanuginosus, showed the maximum production of xylanase activity at $50^{\circ} \mathrm{C}$ with an activity of $14.4 \mathrm{U} / \mathrm{g}$ and the growth about $1.8 \mathrm{mg}$ glucosamine/ $\mathrm{g}$ substrate. A lower activity in the range of 2$10 \mathrm{U} / \mathrm{g}$ and growth of about $1.2 \mathrm{mg}$ glucosamine/ g substrate were obtained. Aspergillus fumigatus showed the maximum production of xylanase activity at $45^{\circ} \mathrm{C}$ with an activity of $11.50 \mathrm{U} / \mathrm{g}$ and the growth about $1.75 \mathrm{mg}$ glucosamine/ $\mathrm{g}$ substrate. A lower activity in the range of $2.34 \mathrm{U} / \mathrm{g}$ and growth of about $1.12 \mathrm{mg}$ glucosamine/ $\mathrm{g}$ substrate were obtained.

The results obtained in our study indicated that the enzyme production corresponded closely to the growth of the fungus. The optimum temperature for xylanase production is similar to the optimum temperature for the growth of the fungus. This observation was in accordance with those reported by Biswas et al., (1990), Sudgen et al., (1994) and who showed that the highest xylanase activities were obtained at temperatures that were optimum for the growth of the fungi in solid-state fermentation. Higher xylanase production was also reported from alkalophilic Bacillus sp. using SSF at the optimum growth conditions (Gessesse and Mamo, 1999).

\section{Effect of Moisture Content}

Humicola lanuginosus, the xylanase production was optimum using the paddy straw which was moistened with moistening agent in the ratio of 1:0.75 Aspergillus fumigatus the xylanase production was optimum with moistening agent in the ratio of 1:0.75 Solid substrates used in SSF are insoluble in water; therefore water will have to be absorbed onto the substrate particles, which can be used by the microorganisms for growth and metabolic activity (Pandey,
1992). It is also expected that the rate of water absorbed by different substrates varies from one substrate to another. This is another possible explanation for the variation in the xylanase production using different substrates. Thus, it is concluded that the degree of hydration of the substrate plays an important role on the growth of the fungi and subsequently the enzyme production. Water causes the swelling of the substrate and facilitates good utilization of substrate by the microorganisms. Increasing moisture level is believed to have reduced the porosity of substrate, thus limiting the oxygen transfer into the substrate Besides distilled water, other moistening agents consisting of mineral salt solution and tap water were also examined. The results show Mineral salts solution and tap water produced higher xylanase production compared to distilled water.

\section{Effect of supplementation of additional carbon and nitrogen sources}

In case of xylose Humicola lanuginosus, showed the maximum production of xylanase activity of $28.50 \mathrm{U} / \mathrm{g}$ and the growth about $2.20 \mathrm{mg}$ glucosamine/ $\mathrm{g}$ substrate. A lower xylanase activity of 15.34 $\mathrm{U} / \mathrm{g}$ and growth of about $1.05 \mathrm{mg}$ glucosamine/ $g$ substrate were obtained in case of control where there is no addition of any of the sugar. Aspergillus fumigatus showed the maximum production of xylanase activity of $22.50 \mathrm{U} / \mathrm{g}$ and the growth about $2.12 \mathrm{mg}$ glucosamine/ $\mathrm{g}$ substrate, here also xylose showed maximum activity. A lower xylanase activity of $10.45 \mathrm{U} / \mathrm{g}$ and growth of about $0.85 \mathrm{mg}$ glucosamine/ $\mathrm{g}$ substrate were obtained in case of control where there is no addition of any of the sugar. Next to xylose, maltose, lactose also showed good activity. In case of cellulose the xylanase activity is less when compare to Xylose. The production of primary metabolites by micro 
organisms is highly influenced by their growth, which is determined by the availability of the nutrients in the substrates. Therefore, it is expected that the improvement of the nutritional value of paddy straw by the supplementation of carbon or nitrogen sources will also improve the growth of Humicola lanuginosus and Aspergillus fumigatus and subsequently the enzyme production. The addition of xylose resulted in an increment of $32 \%$ in xylanase production. Xylose has been described as an effective inducer and carbon source for xylanase production in several microorganisms for xylanase production including A Aspergillus pullulans (Priem et al., 1991), Fusarium oxysporum (Singh et al., 1992) and Thermomyces lanuginosus (Purkarthofer et al., 1993).

Among different nitrogen sources used sodium nitrate showed maximum activity, Humicola lanuginosus, showed the maximum production of xylanase activity of $32.10 \mathrm{U} / \mathrm{g}$ and the growth about $2.45 \mathrm{mg}$ glucosamine/g substrate. A lower xylanase activity of $20.65 \mathrm{U} / \mathrm{g}$ and growth of about $1.65 \mathrm{mg}$ glucosamine/ $\mathrm{g}$ substrate were obtained in case of control where there is no addition of any of the nitrogen source was added. Aspergillus fumigatus showed the maximum production of xylanase activity of $26.65 \mathrm{U} / \mathrm{g}$ and the growth about $1.65 \mathrm{mg}$ glucosamine/ $g$ substrate. Among the nitrogen sources tested, $\mathrm{NaNO}_{3}$ was found to enhance the production of xylanase at $0.075 \%$ (w/ w) by about $46 \%$ compared to the cultivation without the addition of any nitrogen sources. The present results showed no significant difference between the organic or inorganic nitrogen sources on the production of xylanase by Humicola lanuginosus and Aspergillus fumigatus.

\section{Acknowledgement}

Authors are thankful to University Grants
Commission, New Delhi, India for their financial support in the form of Minor research project.

\section{References}

Biswas, S.R., Jana, S.C., Mishra, A.K. and Nanda, G.1990. Production, purification and characterization of xylanase from a hyperxylanolytic mutant of Aspergillus orchraceus. Biotechnol. Bioeng. 35: 244-251.

Gessesse, A. and Gashe, B.A. 1997. Production of alkaline xylanases by an alkaliphilic Bacillus sp.isolated from an alkaline soda lake. J. Appl. Microbiol. 83: 402-406.

Gessesse, A. and Mamo G. 1999. High level xylanase by an alkalophilic Bacillus sp. by using solid state fermentation. Enzyme Microb. Technol.,25: 68-72.

Haltrich, D., Nidetzky, B., Kulbe, K.D., Steiner, W. and Zupaneie, S. 1996. Production of fungal xylanases. Biores. Technol.; 58: 137-161.

Ikasari, L. and Mitchell, D.A. 1994. Protease productionby Rhizopus oligosporus in solid-state fermentation. Appl. Microbiol. Biotechnol. 10:320-324.

Mandels, M., Andreotti, R. and Roche, C. 1976.Measurement of saccharifying cellulase. Biotechnol. Bioeng. Symp. 6: 21-23.

Pandey, A. 1992. Recent process developments in solid-state fermentation. Process Biochem.; 27: 12-17.

Priem, B., Dobberstein, J. and Emeis, C.C. 1991. Productionof $\beta-1,4$-xylanase in continuous culture by Aureobasidium pullulans CBS 58475. Biotechnol.Lett., 13: 149154.

Raimbault, M. and Alazard, D. 1980. Culture method to study fungal growth in solid fermentation. Eur. J. 
Appl. Microbiol. Biotechnol. 9: 199209.

Singh, A., Kumar, P.K.R and Schugerl, K. 1992. Bioconversion of cellulosic materials to ethanol by filamentous fungi. Adv. Biochem. Eng. Biotechnol.; 45:29-55.

Smith, P.J., Rinzema, A., Tramper, J., Schlosser, E.E.and Knol, W. 1996. Accurate determination ofprocess variables in a solid-state fermentation system. Process Biochem. 31: 669-678.

Sudgen, C. and Bhat, M.K. 1994. Cereal straw and pure cellulose as carbon sources for growth and production of plant cell wall degradation enzymes by Sporotrichum thermophile. World J. Microbiol. Biotechnol.; 10: 444451.

Swift, J. 1972. The estimation of mycelial biomass by determination of the hexosamine content of wood tissues decayed by fungi. Soil. Biol. Biochem., 5: 321-322.

Viikari, L., Kantelinen, A., Sundqvist J. and Linko, M. 2001. Xylanases in bleaching: from an idea to the industry. FEMS Microbiol Rev.; 13: 335- 350 .

\section{How to cite this article:}

Anilkumar Hegde and Ramesh, Ch. 2016. Isolation and Screening of Fungi for the Production of Xylanase Using Solid-State Fermentation from Sirsi Region of Western Ghats of Karnataka, India. Int.J.Curr.Microbiol.App.Sci.5(2): 547-556. doi: http://dx.doi.org/10.20546/ijcmas.2016.502.062 